\title{
Facilitating Students Understanding of Biological Phenomena Using Conceptual Change Instructional Model in Enugu Metropolis, Nigeria
}

\author{
Ezechi Nnenna Grace \\ Department of Biology Education \\ Enugu State College of Education (Technical) \\ Enugu, Nigeria
}

\begin{abstract}
Lecture method of teaching adopted by Nigerian biology teachers do not take into cognizance the fact that students construct ideas about natural phenomena before formal instructions in sciences. Some of these ideas called alternative conceptions are different from what is generally accepted in scientific community. Studies have shown that these alternative conceptions are very strong and deeply rooted and if neglected hinder effective teaching and learning. The lecture method of teaching used in Nigerian secondary schools do not recognize these alternative conceptions hence the poor biology achievement. This study, thus, sought to determine if conceptual change instructional model, will better address these alternative conceptions to enhance achievement in Biology. The study adopted quasi experimental design. Two research questions and two hypotheses guided the study. The sample was made up of 282 students. The instrument was a 40item multiple choice Biology Achievement Test (BAT) on genetics. The BAT was face and content validated by experts in measurement and evaluation and Biology Education. A reliability co-efficient of 0.82 was obtained for BAT. Mean and standard deviation were used to answer the research questions while ANCOVA was used to test the null hypothesis. The study revealed that the conceptual change instructional model was more effective in facilitating students' achievement in genetics and that female students achieve better than the males in biology achievement test. The researcher therefore recommended among others the use of appropriate innovative teaching strategies like conceptual change instructional model which recognizes students' prior idea about biological phenomenon before science instructions.
\end{abstract}

\section{Introduction}

Science and technology education is one of the most powerful instruments for enabling members of the society to face new challenges and play roles as productive members of the society [1]. Science helps in the transition of a country from developing to developed world. Science and technology holds the key to the future development of Nigeria or any other country. The sooner Nigeria realizes that her escape from poverty is predicted on her investment in science and technology education, the better for her [2]. [3] Further opined that science is basically about becoming aware, understanding and personal exploration of the environment. This implies that science teaching in schools should enable learners acquire deep understanding of science so as to enhance transfer of knowledge in daily life challenges.

All branches of science have important contributions to make in Nigeria's technological advancement; one of such science subject is biology. Biology is a science subject offered in all the senior secondary schools in Nigeria which attracts greatness patronage of both science oriented and art-based students [4]. The science of biology had been helping mankind in many ways in increasing food production, in combating diseases and in protecting and conserving environment. Biology advances in the field of food and health have resulted in high standard of living. Biology provides us with knowledge of how our body works and what we can do to make it run efficiently [5]. In spite of the popularity of biology among students, the failure rate has remained very high [6]. Available statistical records from west African examination council 2008, 2009, 2010, 2011, 2012, 2013) on secondary school achievement in biology revealed that although biology had the highest enrolment relative to other science subjects, it recorded very poor achievement at the senior secondary certificate examinations. Many researches in science education had been concerned about this downward trend and efforts to identify major factors with the aim of addressing them are being daily projected. The poor performance of students in biology has been attributed to many factors among which is the ineffective instructional strategies used by biology teachers that fail to recognize the prior conceptions or ideas of the students before formal instruction. Most of these ideas called alternative conceptions are unscientific and if neglected hinders effective teaching and learning [7]. Studies have shown that students explain biological phenomena using these alternative conceptions [7]. Implication is that the 
students' alternative conceptions may influence their observations, inferences they draws and what they understand from a formal learning situation. Take for instance in a typical Igbo culture of southeastern Nigeria, recurrent infant mortality in a specific family is attributed to spiritual phenomenon referred to as "ogbanje spirit." It is believed that a demon spirit, "ogbanje”, possessed the children and causes them not to want to live on earth. As a result; the first child to die will reincarnate in a subsequent child, who in turns dies, and so on. Such deaths are believed to recur except where the parents perform some rites in order to appease the gods. These rites are believed to stop further deaths. This is what a scientific explanation will refer o sickle cell phenomenon. Students lack the understanding because of their previous knowledge from their parents and their cultural background. Some students yet have wrong notion about genetic concepts of albinism as punishment from the gods. Ignorance of facts about sex determination made students believe that blame should go to the woman especially if she continuously delivers baby girls. If the students' alternative conceptions are not addressed, they may take these ideas along as they progress. This study thus sought to determine if a new model, conceptual change instructional model, will better address these alternative conceptions thereby enhancing achievement.

Gender as a factor in academic attainment has been the concern of educationist, teachers and administrators over the years [8]. Different researches have offered varying hypotheses to explain their observed gender differences in academic attainments. Some researchers like [9] have shown that gender plays no significant role in biology achievement. According to [10], performance of girls is lower than that of boys in biology. Also, [11] discovered that female students tend to demonstrate superior conceptual understanding of force and motion than the male counterparts. Considering all these views, one cannot draw any meaningful conclusion on the effect of gender on academic achievement since studies on gender differences in achievement are still inconclusive. The researcher therefore considers it worthwhile to investigate the influence of gender on achievement.

\section{Literature Review}

Conceptual change is defined as a learning process in which an existing conception (idea or belief about how the world works) held by the students is shifted and restructured, often away from alternative conceptions and towards the dominant conceptions held by experts in the field [12]. Conceptual change is generally defined as learning that changes existing conceptions and belief, idea, or way of thinking [13], [7] reported that what a student learns result from interaction between what is bought to learning situation (by the learner) and what is experienced in it and the interaction results in restructuring of conceptions or conceptual change. [14] and [7] have provided both empirical and theoretical supports for constructivist-based model like conceptual change instructional model. [14] defined this model as the method of instruction which accepts a child's ownership of idea, treat those ideas with respect they deserve and encourages a negotiation or renegotiation of these ideas in a social context with the aim of assisting the child to restructure or reconstruct his conceptions on the basis of confrontation with contextualized evidence. Such a method results in a conceptual / paradigmatic change or shift. [15] cited in [16] posited that conceptual change instructional model is characterized by:

(a) Intelligibility - how understandable or meaningful the concept is.

(b) Plausibility - how believable or consistent with the child's worldview the concept is.

(c) Dissatisfaction with existing conceptions: the new evidence must create in the child a sense of dissatisfaction with his prior conceptions which are intuitive.

(d) Fruitfulness: the new concept must find application in new life situation.

[17] Conceptual change instructional model as cited in [16] comprises the following five steps:

\section{Step 1: Determination of prior conceptual} alternative framework held by the students.

Students develop knowledge of physical world right from birth. Some of these conceptions are illogical and intuitive. The goal of modern science instruction is to help the students to restructure these alternative frameworks. Hence the beginning of any viable science instruction is "the personal knowledge of the learner".

\section{Step 2: exploration of phenomena.}

This step involves presenting activities that tend to counter the prior conceptions of students.

\section{Step 3: Discussion of result of activities.}

Through the result of the experiences /activities in step 2, the students are led to arrive at scientifically accepted principles. Here the science teacher should use questioning technique in directing students thinking.

Step 4: Development of dissatisfaction with prior/preexisting conception.

The logical interpretations or scientifically accepted concepts arrive at step 3 are compared with preexisting conceptions as identified in step 1. If there are still illogical or intuitive conceptions, the teacher returns to step 2 otherwise, the instruction should progress to the next step.

Step 5: Application 
This stage offers the opportunity to use the concept in a real-life situation. The learners are asked to provide example of the concepts in real life situation. [7] recommended that alternative conceptions of the students should be identified and reduced to barest minimum using conceptual change instructional model.

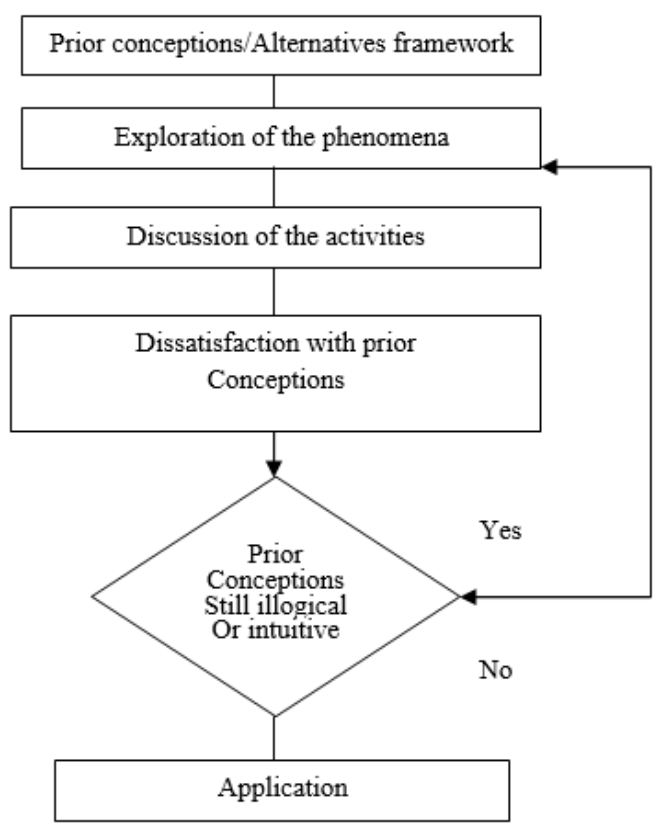

The model presented here, PEDDA, is an adaptation of that proposed by [17]. The term PEDDA is an acronym derived from the initial letter of the process in the five steps of the model.

\section{Research Questions}

(1) What are the mean achievement scores of SS3 biology students taught with conceptual change instructional model and those taught with lecture method of teaching as measured by biology achievement test (BAT).

(2) What are the mean achievement scores and standard deviations of male and female students as measured by Biology Achievement Test (BAT)?

\section{Hypothesis}

The following hypotheses are tested at (0.05) level of significance

HO1: There is no significant difference in the mean achievement scores of biology students taught with conceptual change instructional model and those taught with lecture method of teaching.

HO2: There is no significant difference in the mean achievement scores of male and female biology students as measured by BAT.

\section{Methods and Methodology}

The design used in this study is the quasiexperimental design. The specific quasi experimentation that was used is the pretest-posttest non-equivalent, control group design. The design was used because of non-randomization of subjects. The research subjects were not randomized because of problems of rearrangement or regrouping of classes. Intact classes were therefore used in order not to disrupt the school administration. The use of the design is justified by the fact that intact classes that were not equivalent were used. However, the intact classes were randomly assigned to either the experimental or control group.

The population of the study comprised all senior secondary class three (SS3) students, who were offering biology in all the state owned secondary schools in Enugu education zone of Enugu State, Nigeria in 2014/2015 academic session. There are 23 secondary schools in the zone with a population of three thousand, seven hundred and eighty-eight students (3788). The SS3 students were in their final year of secondary school and the choice of this level of education was based on the fact the students have all taken some introductory lessons on genetics e.g chromosomes, mitosis, meiosis in their first 2 years of senior secondary school.

The sample consists of 282 SS3 biology students, randomly drawn from four (4) out of 23 government owned secondary schools in Enugu Education zone. Purposive and random sampling techniques were used for the study. Four (4) single sex schools (2 males and two females) were purposely selected from the zone. Thus, having two schools (a male and female) for experimental group and another two (a male and female) schools for the control group. Two intact SS3 classes in each school was selected using random sampling (balloting by replacement). In each school, one intact class was assigned to conceptual change instructional model (experimental group) while the other intact class was assigned to lecture method of teaching (control group). The selection of the classes for the instructional packages was done through simple random sampling (balloting). All the students in each of the intact classes were used for the study. The experimental sample $(\mathrm{N}=137)$ consisted of 64 females and 73 males while the control group sample $(\mathrm{N}=145)$ consisted of 63 females and 82 males.

The instrument used to collect and generate data was a Biology Achievement Test (BAT). The BAT is a 40 -item multiple test developed by the researcher. The alternative conceptions identified in literature were used as distracters in preparation of BAT. The instrument was used for both pretest and posttest but was rearranged during post testing. The instrument was face and content validated by two experts in biology Education and one expert in measurement 
and evaluation from faculty of Education, Enugu State University of Science and Technology. The reliability of the instrument was determined using Kuder-Richardson's formula-20 (K-R 20). The internal consistency index obtained for BAT was 0.82 .

Two instructional approaches were employed for the study. The first is the conceptual change instructional model (CONMOD) while the second one was lecture method. The two approaches were identical in terms of content coverage, time and method of evaluation. The only difference was instructional activities where conceptual change instructional model (CONMOD) deviated from lecture method by employing constructivist principles and theories during instructional process. The CONMOD was used for the experimental group while the lecture method was used for the control group. The regular Biology teachers in the schools were used for the study. All the biology teachers used received a one-week training from the researcher on the instructional package types. Before treatment, the research subjects were given a pretest. It was after the pretest that the regular biology teachers commenced teaching in their schools, using the instructions on the lesson notes given to them by the researcher. The teaching was done using the normal school periods and following the normal lesson periods of the school. At the end of the experiment, which lasted for four weeks, the biology teachers administer the posttest to the research subjects in the two groups. Data collected from the pretest and posttest was kept separately for the two groups and was used to answer the research questions and test the hypothesis.

Research questions one and two were answered using mean and standard deviation. Two-way analysis of covariance (ANCOVA) was used to test the hypothesis at 0.5 alpha level. In terms of content coverage, the researcher selected genetics. The choice of genetics was justified by the fact the genetics have been identified as a difficult concept in Biology. The selection of genetics was also based on the alternative conceptions widely held by students on genetics concepts as reported in literature [18]. The topics selected under genetics include chromosome mutation, sickle cell anaemia, Albinism and sex determination.

\section{Analysis of Findings}

Result obtained from the analyzed data were presented below based on the research questions and hypothesis. Table 1 indicates that the experimental group obtained mean achievement scores of 3.39 and 26.11 respectively in the pretest and posttest.
Table 1. Mean achievement scores of subject taught genetics using CONMOD and lecture method

\begin{tabular}{|c|c|c|c|c|c|c|c|}
\hline \multirow[t]{2}{*}{ Group } & \multicolumn{3}{|c|}{ Mean X } & \multicolumn{3}{|l|}{$\begin{array}{l}\mathrm{S} \\
\mathrm{D}\end{array}$} & \multirow[t]{2}{*}{$\mathbf{N}$} \\
\hline & Pretest & $\begin{array}{c}\text { Posttes } \\
\mathbf{t}\end{array}$ & $\begin{array}{c}\text { Gain } \\
\text { Scor } \\
\text { e }\end{array}$ & $\begin{array}{l}\text { Pret } \\
\text { est }\end{array}$ & $\begin{array}{l}\text { Pos } \\
\text { ttes } \\
\text { t }\end{array}$ & $\begin{array}{l}\text { Gain } \\
\text { Score }\end{array}$ & \\
\hline $\begin{array}{l}\text { Experi } \\
\text { mental } \\
\text { (CON } \\
\text { MOD) }\end{array}$ & 3.39 & 26.11 & $\begin{array}{c}22.7 \\
2\end{array}$ & 2.80 & $\begin{array}{l}5.8 \\
7\end{array}$ & 4.96 & 137 \\
\hline $\begin{array}{l}\text { Control } \\
\text { (Lectur } \\
\text { e } \\
\text { Metho } \\
\text { d) }\end{array}$ & 3.63 & 14.54 & $\begin{array}{c}10.9 \\
0\end{array}$ & 2.89 & $\begin{array}{l}6.0 \\
7\end{array}$ & 5.07 & 145 \\
\hline
\end{tabular}

The subjects also got standard deviations of 2.80 and 5.87 in the pretest and posttest respectively. On the other hand, the control group had mean scores of 3.63 and 14.54 respectively in the pretest and posttest. The standard deviations of the control in the pretest and posttest were 2.89 and 6.07 respectively. The result indicates that the experimental group differed from the control in the mean achievement score by 11.57 . The difference is in favor of the experimental group.

Table 2. Mean achievement scores and standard deviations of male and female students taught genetics

\begin{tabular}{|l|l|l|l|l|l|l|l|}
\hline \multicolumn{4}{|c|}{ Mean(x) } & \multicolumn{3}{|c|}{ Standard deviation } & \\
\hline Group & $\begin{array}{l}\text { Pre } \\
\text { test }\end{array}$ & $\begin{array}{l}\text { Postt } \\
\text { est }\end{array}$ & $\begin{array}{l}\text { Gain } \\
\text { Score }\end{array}$ & $\begin{array}{l}\text { Pret } \\
\text { est }\end{array}$ & $\begin{array}{l}\text { Postt } \\
\text { est }\end{array}$ & $\begin{array}{l}\text { Gain } \\
\text { Score }\end{array}$ & N \\
\hline Female & 3.18 & 20.46 & 17.28 & 2.65 & 8.87 & 8.36 & 127 \\
\hline Male & 3.79 & 19.91 & 16.12 & 2.97 & 7.85 & 7.19 & 155 \\
\hline
\end{tabular}

Table 2 indicates that all the females irrespective of method obtained mean scores of 3.18 and 20.46 in the pretest and posttest respectively and standard deviations of 2.65 and 8.87 respectively in the pretest and posttest. On the other hand, all the males irrespective of the method used obtained means scores of 3.79 and 19.91 in the pretest and posttest respectively. The standard deviations for all males in the pretest and posttest were 2.97 and 7.85 respectively. The result indicates that male students differed from the female students in mean biology achievement score by 0.55 . This slight difference is in favour of female students. 


\section{Test of Null Hypothesis}

These hypotheses were tested at .05 level of significance, using analysis of covariance, (ANCOVA). Summary of the analysis for the two null hypotheses that guided the study is shown in table 3.

Table 3. Analysis of covariance (ANCOVA) for students' mean achievement scores by instructional package type and gender

\begin{tabular}{|c|c|c|c|c|c|c|}
\hline $\begin{array}{l}\text { Source of } \\
\text { variation }\end{array}$ & $\begin{array}{l}\text { Sum of } \\
\text { squares }\end{array}$ & Df & $\begin{array}{l}\text { Mean } \\
\text { square }\end{array}$ & F-cal & f-crit & $\begin{array}{l}\text { Dec } \\
\text { isio } \\
\mathbf{n}\end{array}$ \\
\hline $\begin{array}{l}\text { PRETEST } \\
\text { Covariates } \\
\text { posttest }\end{array}$ & 666.101 & 1 & 666.101 & 118.480 & 3.840 & $\mathrm{~S}$ \\
\hline $\begin{array}{l}\text { Main effect } \\
\text { Method } \\
\text { Sex }\end{array}$ & $\begin{array}{l}398.269 \\
367.150 \\
28.973\end{array}$ & $\begin{array}{l}2 \\
1 \\
1\end{array}$ & $\begin{array}{l}199.134 \\
367.150 \\
28.973\end{array}$ & $\begin{array}{l}35.420 \\
65.305 \\
5.153\end{array}$ & $\begin{array}{l}3.000 \\
3.840 \\
3.840\end{array}$ & $\begin{array}{l}\mathrm{S} \\
\mathrm{S} \\
\mathrm{S}\end{array}$ \\
\hline $\begin{array}{l}\text { 2-way } \\
\text { interaction } \\
\text { Sex x } \\
\text { method } \\
\text { Residual } \\
\text { Total }\end{array}$ & $\begin{array}{l}.484 \\
1557.305 \\
2270.411\end{array}$ & $\begin{array}{l}1 \\
277 \\
281\end{array}$ & $\begin{array}{l}.484 \\
5.622 \\
8.080\end{array}$ & .086 & 3.840 & NS \\
\hline
\end{tabular}

$\mathrm{S}=$ Significant, NS = Not significant at .05 level of probability.

\section{Null Hypothesis 1}

For hypothesis 1, Table 3 shows that the calculated F- ratio (F-cal) due to instructional model is 65.305 while F critical value is 3.840 . Since the calculated value is greater than the critical value, the null hypothesis is rejected. The researcher, therefore, concludes that there is a significant difference in the mean achievement scores of biology students taught with conceptual change model and those taught with lecture method of teaching.

\section{Null Hypothesis 2}

For hypothesis 2, table 3 shows that F-cal due to sex is 5.153 and F-critical is 3.840 at an alpha level of .05. The null hypothesis is rejected. The researcher concluded that there is a significant difference in the mean achievement scores of male and female biology students as measured by Biology Achievement Test (BAT).

\section{Discussion}

Result from table 1 showed the effect of teaching methods on students' achievement in genetics. The mean achievement scores of the students in the experimental control were higher than the mean achievement scores of students in the control group. This was further confirmed by the result in table 3 which revealed that method was a significant factor on students' achievement in genetics. Thus it was confirmed that students taught genetics using conceptual change instructional model performed better than those taught using the lecture method. This implies that conceptual change instructional model was more effective in enhancing and facilitating students' academic achievement in genetics than lecture method. The findings of this study seems to support the findings of [9] that confirmed that appropriate teaching method leads to students improved achievement in Biology and the work of [14] that attributed under achievement partly to lecture method of teaching where lecture are taught theoretically and based on teacher's dominance. The researcher is of the view that since conceptual change instructional model explores and addresses the alternative conceptions of students, one would expect that it will foster conceptual change and enhance achievement in Biology.

Result in table 2 show that females achieve better than males in biology achievement test. The findings was confirmed by the result in table 3 that there a significant difference in the mean achievement scores of male and female biology students. This is in line with the work of [11] that female student tend to demonstrate superior conceptual understanding than their male counterpart. This is not in line with the work of [10] who discovered that performance of girls is lower than that of the boys in biology and [9] that gender plays no significant role in biology achievement.

\section{Conclusion}

From the results obtained, the researcher drew the conclusion that there is a significant difference in biology achievement of secondary senior class three (SS3) students taught with conceptual change instructional model and those taught with lecture method, the difference is in favor of conceptual change instructional model. Again, females achieved better than males in Biology Achievement Test. It is thus expected that emphasis should be placed on this constructivist package, the conceptual change instructional method, which addresses the alternative conceptions of students.

\section{Recommendations}

Based on the findings of the study, the following recommendations are made.

(1) Biology teachers expected to teach for conceptual change should be exposed to conceptual change packages during their pre-service years. 
(2) The alternative conceptions of students should be identified and reduce to barest minimum using conceptual change instructional packages.

(3) Conferences/workshops on conceptual change instructional model should be organized for serving teachers and curriculum developers.

(4) Biology teachers should incorporate conceptual instructional package as one of the methods used in teaching of biology.

\section{References}

[1] Mbah, H.N (2007). 'Refocusing S/T Education for National development multi-disciplinary journal in knowledge builder' 15(9), 76-79.

[2] Egbogah, E.O. (2012) 'The role of science and Technology in National Development'. Petroleum Technology Development Journal Vol 279.

[3] Erinosho, M.C (2006). Operational thought and achievement level of secondary schools, their amenability to modern instructional techniques in science. Senated research project, Ondo state university Akure.

[4] Nwosu, O. (2006). 'Science Teachers role in Breaking Gender Barriers in Science, Technology and Mathematics education'. Gender and STM Education series No 1 STAN, 46-58.

[5] Web Desk (2015). 'The importance of Biology' https://medicalopedia.org/4974/the-importance-ofbiology/.

[6] Akubuilo, D.U. (2004). 'The effect of problem solving instructional strategies on students' achievement and retention in biology with respect to location in Enugu state'. Journal of the science Teachers Association of Nigeria, 24(1\&2), 94-100.

[7] Iloputaife E.C (2001). Effect of analogy and conceptual change instructional model in physics achievement of secondary school students unplubished Ph.D thesis, University of Nigeria Nsukka.

[8] Abdu-Raheem, B.O (2012). 'Gender differences and students' Academic Achievement and Retention in social studies among junior secondary schools in Ekiti state, Nigeria.' European Journal of Education Studies (4), 155161.

[9] Nwagbo, C \& Obiekwe.C. (2010). 'Effects of constructivist instructional approach on Students Achievement in Basic Ecological Concepts in Biology'. Journal of Science Teacher's Association of Nigeria 45, 1\&2, 26-35.

[10] Anidu, I.C.(2007). A comparative Study of Cooperative learning and concept mapping instructional strategies on senior secondary students' achievement, interest and retention in biology. An unpublished MSC thesis, ESUT Enugu.
[11] Eshetu, A.A. (2015). 'Gender disparity analysis in academic achievement at higher education preparatory schools. Case of South wollo, Ethiopia'. Educational Research Reviews, 10(1), 50-58.

[12] Tanner, K. \& Allen , D. (2005). 'Approaches to Biology Teaching and learning: Understanding the wrong answers - teaching towards Conceptual change'. Cell biology Education, vol. 4, 112-117

[13] Davis, J. (2001). Conceptual change in M.orey(Ed) Emerging perspectives on learning, teaching and technology. Retrieved from http://epltt.coe.uga.edu/

[14] Nworgu, B.G (1996). Teaching for conceptual understanding of physics: a conceptual change instructional model. A lead paper presented at the 37th annual conference of STAN.

[15] Posner, G.F, Strike, K.A, Hewson, P.W Gertzog, W.A (1982). 'Accommodation of a scientific conception: towards a theory of conceptual change.' Science Education 66(22), 221-227.

[16] Ezechi, N.G (2014). Senior Secondary School Students reasoning patterns and their Achievement in genetics and Evolution in Enugu metropolis, Nigeria. Unpublished Ph.D thesis, University of Nigeria Nsukka.

[17] Stofflet, R.T. \& Stoddart, T. (1994). 'The ability to understand the use of conceptual change pedagogy as a function of prior content learning experience'. Journal of Research in Science Teaching 31(1), 31-51.

[18] Mbajiorgu, N.M (2003). Science: The teachers perspective Enugu Institute of Development Studies, University of Nigeria, Enugu Campus. 